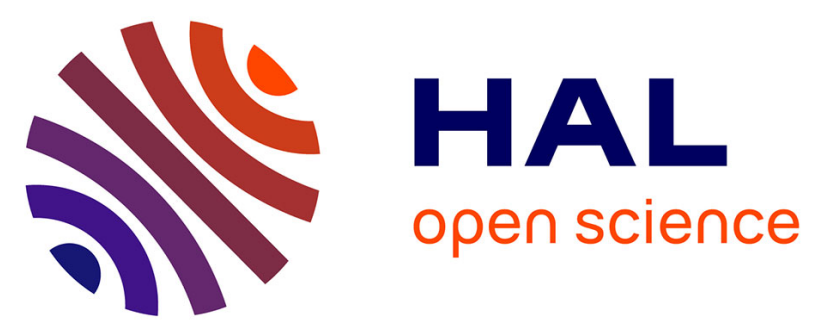

\title{
Teasing apart activities of different types of ABC efflux pumps in bivalve gills using the concepts of independent action and concentration addition
}

Till Luckenbach, Rolf Altenburger, David Epel

\section{- To cite this version:}

Till Luckenbach, Rolf Altenburger, David Epel. Teasing apart activities of different types of ABC efflux pumps in bivalve gills using the concepts of independent action and concentration addition. Marine Environmental Research, 2008, 66 (1), pp.75. 10.1016/j.marenvres.2008.02.027 . hal-00501947

\section{HAL Id: hal-00501947 \\ https://hal.science/hal-00501947}

Submitted on 13 Jul 2010

HAL is a multi-disciplinary open access archive for the deposit and dissemination of scientific research documents, whether they are published or not. The documents may come from teaching and research institutions in France or abroad, or from public or private research centers.
L'archive ouverte pluridisciplinaire HAL, est destinée au dépôt et à la diffusion de documents scientifiques de niveau recherche, publiés ou non, émanant des établissements d'enseignement et de recherche français ou étrangers, des laboratoires publics ou privés. 


\section{Accepted Manuscript}

Teasing apart activities of different types of ABC efflux pumps in bivalve gills using the concepts of independent action and concentration addition

Till Luckenbach, Rolf Altenburger, David Epel

PII:

S0141-1136(08)00035-4

DOI:

10.1016/j.marenvres.2008.02.027

Reference:

MERE 3187

To appear in:

Marine Environmental Research

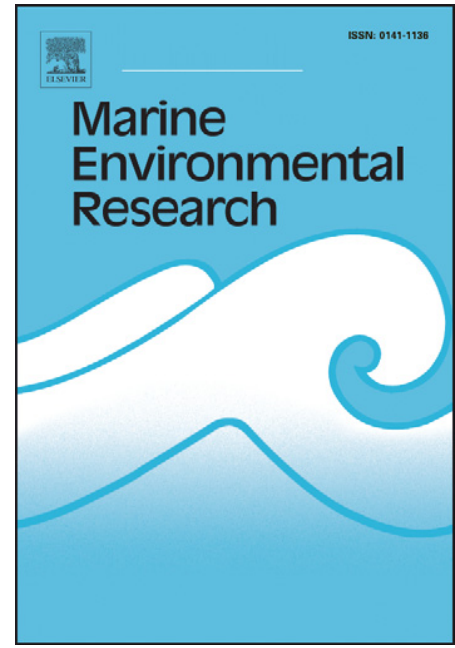

Please cite this article as: Luckenbach, T., Altenburger, R., Epel, D., Teasing apart activities of different types of ABC efflux pumps in bivalve gills using the concepts of independent action and concentration addition, Marine Environmental Research (2008), doi: 10.1016/j.marenvres.2008.02.027

This is a PDF file of an unedited manuscript that has been accepted for publication. As a service to our customers we are providing this early version of the manuscript. The manuscript will undergo copyediting, typesetting, and review of the resulting proof before it is published in its final form. Please note that during the production process errors may be discovered which could affect the content, and all legal disclaimers that apply to the journal pertain. 


\title{
Teasing apart activities of different types of $\mathrm{ABC}$ efflux pumps
}

\section{in bivalve gills using the concepts of independent action and concentration addition}

\author{
Till Luckenbach $^{\text {a,b,*, }}$, Rolf Altenburger ${ }^{\text {a }}$, David Epel ${ }^{\text {b }}$ \\ ${ }^{a}$ UFZ - Helmholtz Centre for Environmental Research, 04318 Leipzig, Germany \\ ${ }^{b}$ Hopkins Marine Station, Stanford University, Pacific Grove, CA, 93950, USA
}

\begin{abstract}
Fluorescent dyes and inhibitor compounds are commonly used to detect activity of multixenobiotic resistance (MXR) efflux pumps in marine invertebrates. We here address the question whether compounds acting as specific inhibitors of certain mammalian transporters can be used in dye efflux assays to distinguish different transporter activities in gill tissue from a marine mussel. We quantified effects of PSC833, a specific inhibitor of mammalian P-gp (P-glyoprotein, ABCB1), and MK571, which blocks MRP (Multidrug resistance associated protein, $\mathrm{ABCC}$ ) type transporters, on calcein-am efflux in gill tissue of Mytilus californianus. Calcein-am acts as a substrate of both P-gp and MRP. Effects of single compounds and mixtures were determined and combined effect models predicting independent action (IA) and concentration addition (CA) of the chemicals were applied. Effect values predicted by IA showed better correspondence with the experimentally obtained data. This indicates that the inhibitor compounds target different mechanisms of
\end{abstract}


calcein-am efflux and points to P-gp and MRP activities in mussel gills. Our approach could be a simple way for identifying the efflux transporter types targeted by chemosensitizers, including environmentally relevant compounds, in native tissues from marine invertebrates.

Keywords: Concentration addition; Independent action; Mixtures; MRP; Multixenobiotic resistance; Mytilus californianus; P-gp

*Corresponding author: UFZ - Helmholtz Centre for Environmental Research, Department Cell Toxicology, Permoserstr. 15, D - 04318 Leipzig, Germany; Tel: +49 - (0)341-235

2433, fax:+49 - (0)341-235 2434

Email address: till.luckenbach@ufz.de 
Multixenobiotic resistance (MXR) is conferred by membrane-based proteins from the ABC (ATP binding cassette) transporter family. These proteins act as efflux pumps against multiple, chemically unrelated compounds and provide a cellular defense against toxicants. High activity of these transporters has been found in a range of species and this activity can protect against xenobiotics.

In earlier studies, transporter activity in aquatic organisms was mainly associated with P-glycoprotein (P-gp) (Kurelec, 1992). However, more recent papers show that the MXR system of aquatic organisms could arise from many different transporter types. For instance, the genome of the sea urchin Strongylocentrotus purpuratus contains 65 ABC transporters, with many being homologous to known mammalian xenobiotic transporters (Sodergren et al., 2006). Transcripts and activities of different xenobiotic transporter types were also identified in tissues from bivalves (Luedeking and Koehler, 2002, Luckenbach and Epel, submitted), including full-length P-gp and MRP type transcripts with 40-49\% amino acid identity with human P-gp and 33-45\% identity with human MRP transporters (Luckenbach and Epel, submitted).

We here ask whether one can distinguish the activities of these different transporters from the mussel Mytilus californianus with specific inhibitors of mammalian ABC transporters. Studies on mammalian transporters indicate specific inhibition of P-gp by PSC833 (Mayer et al., 1997) and of MRP by MK571 (Gekeler et al., 1995). However, functional properties of homologous transporters may vary among species and it is therefore not clear whether those compounds are also useful to determine specific activities of transporters in other taxa.

Transporter activity was assessed using calcein-am (c-am) (Molecular Probes; Eugene, OR, USA), which is a substrate of both the P-gp and MRP transporters (Essodaigui et al., 1998). The compound is non-fluorescent, but once it enters the cell it is 
hydrolyzed by endogenous esterases and fluorescent calcein is formed. This fluorescent product is trapped in the cell since it is a poor substrate for these transporters.

Accumulation of calcein in gill tissue was determined in the presence of different concentrations of PSC833 (kind gift of Novartis; Basel, Switzerland) (range 0.1 - $20 \mu \mathrm{M}$ ) and MK571 (Cayman Chemicals; Ann Arbor, MI, USA) (range $0.1-50 \mu \mathrm{M}$ ). Additionally, combinations of PSC833 and MK571 (range $0.2-20 \mu \mathrm{M}$ ) were applied as equimolar mixtures (e.g., the mixture with a total of $10 \mu \mathrm{M}$ of inhibitor contained $5 \mu \mathrm{M}$ of each, PSC833 and MK571). The dye efflux assay was performed according to Luckenbach and Epel (2005). Briefly, equally sized discs (5 mm diameter) prepared from gill tissue of a freshly dissected mussel were incubated in filtered seawater (FSW) for 90 min at $15^{\circ} \mathrm{C}$ with $0.25 \mu \mathrm{M}$ c-am and varying concentrations of test compounds and their mixtures along with a control with c-am only. The discs were then rinsed, homogenized with a lysis buffer (10 mM KCl, $1.5 \mathrm{mM} \mathrm{MgCl}_{2}, 10 \mathrm{mM}$ Tris $\left.\mathrm{HCl}, \mathrm{pH} 7.4\right)$ and centrifuged to remove tissue debris. Fluorescence of the tissue extracts with calcein was then measured with a microplate reader (emission: $530 \mathrm{~nm}$, excitation: $485 \mathrm{~nm}$ ). Each concentration was tested in at least 3 independent experiments with gill tissue from different animals.

The effects of the PSC833 and MK571 mixtures were then analyzed using models that predict actions of chemical mixtures by concentration addition (CA) and by independent action (IA) based on the dose-response functions of the individual compounds (Fig. 1). The CA model is based on the pharmacodynamic assumption that the mixture components act through a similar mechanism, whereas IA describes effects by components acting on different targets (Altenburger et al., 2003). Their usefulness as a pharmacological probe for similar or dissimilar action has recently been demonstrated (Altenburger et al., 2005). 
As seen in Fig. 1, there was a concentration dependent increase in calcein accumulation in the gill tissue with both inhibitors. This shows presence of transporter activity in the gills that is sensitive to both inhibitors since inhibiting the activities resulted in increased levels of the substrate. Low levels of either inhibitor caused a slow linear increase in calcein accumulation between zero and $2 \mu \mathrm{M}$. Above $2 \mu \mathrm{M}$ however, the PSC833 inhibition continued to increase linearly, whereas the MK571 inhibition had more of an exponential increase. In the lower concentration range inhibition by the PSC 833 and MK571 mixture did not largely differ from inhibition by the single compounds, but at concentrations above $2 \mu \mathrm{M}$ inhibitory effects by the mixture were greater than by any of the single compounds.

Applying the CA and IA modelling it is observed that the inhibition of transporter activity by the PSC833 and MK571 mixture corresponds better to the independent action mode of inhibition (IA) than to the concentration addition mode (CA). This result is consistent with the assumption that PSC833 and MK571 affect two different mechanisms of calcein-am efflux in mussel gill. Although specificities of PSC833 and MK571 for mussel P-gp and MRP need to be corroborated in more specific test systems, such as transfected cells, our finding corresponds to the presence of P-gp and MRP transcripts in gill tissue (Luedeking and Koehler, 2002; Luckenbach and Epel, submitted) and therefore is an indication of both types of activities in the gills.

Our data show that analyzing effects of chemical mixtures based on the concepts of IA and CA enables to distinguish different kinds of efflux in mussel gills. This approach can be useful to identify transporters targeted to different chemicals and also assess the contribution these transporters make to MXR. The approach will also be useful in risk assessment to determine which components of the MXR defense are involved in 
chemosensitization, which is the inhibition of transporter function by certain environmental chemicals (Luckenbach and Epel, 2005).

\section{Acknowledgements}

This publication was supported in part by the Deutsche Forschungsgemeinschaft (DFG), the National Sea Grant College Program of the U.S. Department of Commerce's National Oceanic and Atmospheric Administration under grant R/CZ-182 through the California Sea Grant College Program, and the California State Resources Agency.

\section{References}

Altenburger, R., Nendza, M., and Schüürmann, G. (2003). Environmental Toxicology and Chemistry, 22, 1900-1915.

Altenburger R., Schmitt H., and Schüürmann, G. (2005). Environmental Toxicology and Chemistry, 24, 324-333.

Essodaigui, M., Broxterman, H. J., and Garnier-Suillerot, A. (1998). Biochemistry, 37, 2243-2250.

Gekeler, V., Ise, W., Sanders, K. H., Ulrich, W. R., and Beck, J. (1995). Biochemical and Biophysical Research Communications, 208, 345-352.

Kurelec, B. (1992). Critical Reviews in Toxicology, 22, 23-43.

Luckenbach, T., and Epel, D. (2005). Environmental Health Perspectives, 113, 17-24.

Luckenbach, T., Epel, D. (submitted). American Journal of Physiology - Regulatory, Integrative and Comparative Physiology.

Luedeking, A., and Koehler, A. (2002). Marine Ecology Progress Series, 238, 115-124. 
Mayer, U., Wagenaar, E., Dorobek, B., Beijnen, J. H., Borst, P., and Schinkel, A. H. (1997). Journal of Clinical Investigation, 100, 2430-2436.

Sodergren, E., Weinstock, G. M., Davidson, E. H., Cameron, R. A., Gibbs, R. A., Angerer, R. C., et al. (2006). Science, 314, 941-952. 


\section{Figure caption}

Fig. 1. Effects of pharmacologic ABC transporter inhibitors PSC833 and MK571 on calcein accumulation in gill tissue from mussel Mytilus californianus. Changes of calcein accumulation in gill tissue discs from different treatments is indicated by changes in fluorescence signal strength. An increase in calcein accumulation in the tissue is used as a measure for reduced efflux of calcein-am by $\mathrm{ABC}$ transporter proteins in cells of the gill. Inhibitors were applied as single compounds and as mixtures. Additionally, combined effects of the inhibitors were predicted using concentration addition (CA) and independent action (IA) models based on the dose-response functions of the individual compounds. The CA model only predicts values up to the maximal effect of the least effective compound, which was estimated at $255 \%$ for PSC833. Therefore the CA curve does not continue beyond this value. Dose-response curves of the individual compounds are based on data from 3 to 9 independent experiments. For fitting the curves, individual data points from all experiments for each concentration were used. Symbols of observed combined effects each represent a data point from a separate experiment (4 experiments per concentration). 
Figure 1

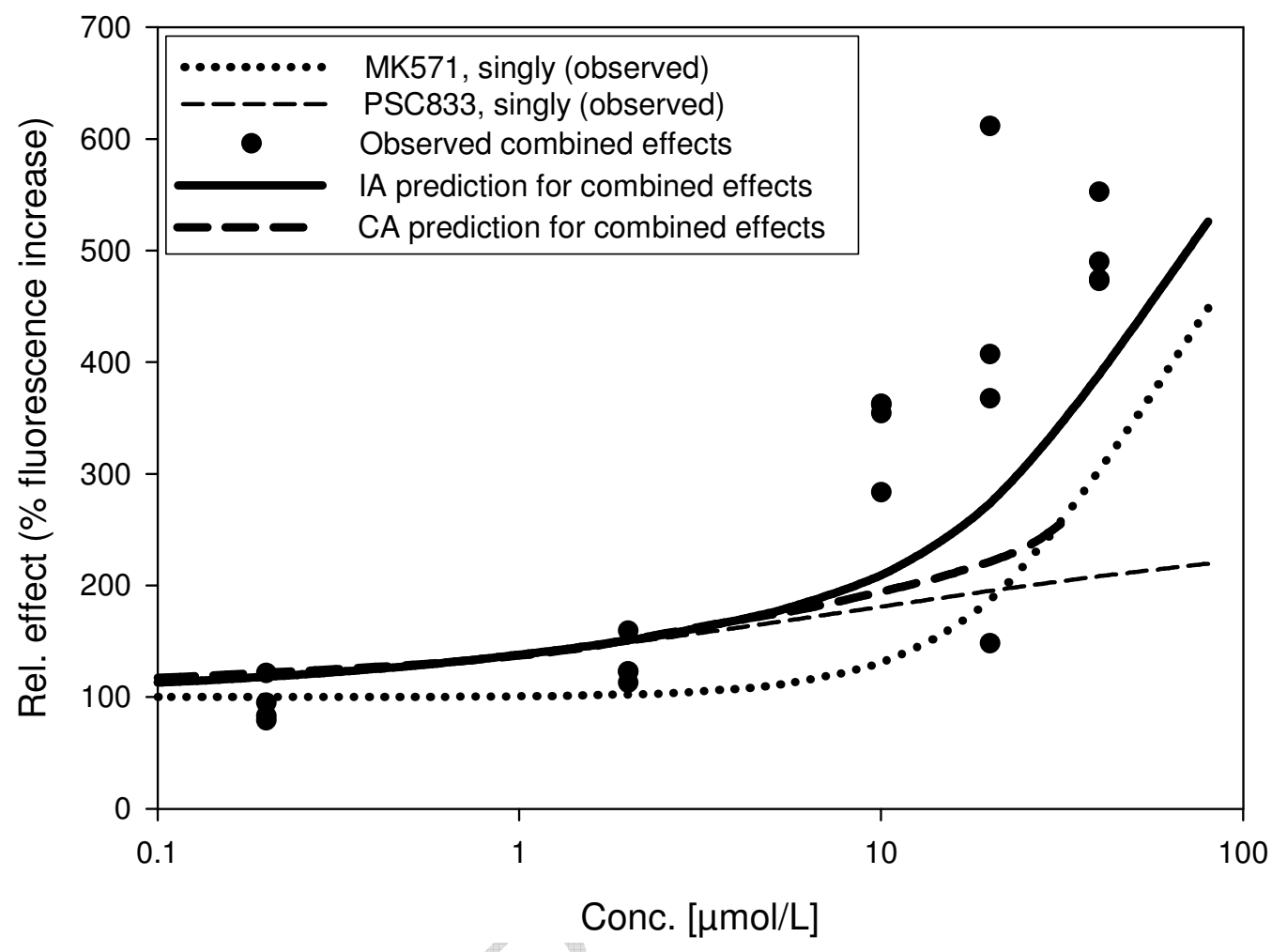

